\title{
Quality of life of master's and doctoral students in health
}

\author{
Qualidade de vida de estudantes de mestrado e doutorado da área da saúde \\ Calidad de vida de los estudiantes de maestría y doctorado en el ámbito de la salud
}

Flaviane Cristina Rocha Cesar' ORCID: 0000-0002-2659-2871

Lizete Malagoni de Almeida Cavalcante Oliveira' ORCID: 0000-0002-1055-1354

Luana Cássia Miranda Ribeiro ORCID: 0000-0002-4254-2030

Angela Gilda Alves' ORCID: 0000-0001-8709-8933

Katarinne Lima Moraes" ORCID: 0000-0001-6169-0461

Maria Alves Barbosa ORCID: 0000-0002-0861-9655

'Universidade Federal de Goiás. Goiânia, Goiás, Brazil. "Universidade Federal de Jataí. Jataí, Goiás, Brazil.

How to cite this article: Cesar FCR, Oliveira LMAC, Ribeiro LCM, Alves AG, Moraes KL, Barbosa MA. Quality of life of master's and doctoral students in health. Rev Bras Enferm. 2021;74(4):e20201116. https://doi.org/10.1590/0034-7167-2020-1116

\section{Corresponding author:}

Flaviane Cristina Rocha Cesar E-mail: flaviane_rocha01@hotmail.com

EDITOR IN CHIEF: Antonio José de Almeida Filho ASSOCIATE EDITOR: Alexandre Balsanelli

Submission: 11-09-2020 Approval: 01-11-2021

\begin{abstract}
Objectives: to assess the quality of life of master's and doctoral students in health. Methods: this is a cross-sectional study carried out with 503 master's and doctoral students from the Brazilian Center-West, using the WHOQOL-BREF to analyze their quality of life. Analysis included Cronbach's alpha coefficient, confirmatory factor analysis and bivariate and multivariate analyzes. Results: older age and having a child were associated with higher average quality of life scores, while diagnosis of anxiety/depression, difficulty in managing academic and personal activities and thinking about dropping out of course were associated with lower average scores in quality of life domains $(p<0.05)$. Conclusions: master's and doctoral students have reduced quality of life during the entire training period, mainly in psychological and physical health. The management of academic activities and dropping out of course are the main variables associated with decreased students' quality of life.
\end{abstract} Descriptors: Quality of Life; Education, Graduate; Students; Mental Health; Health Occupations.

\section{RESUMO}

Objetivos: avaliar a qualidade de vida de estudantes de mestrado e doutorado da área da saúde. Métodos: estudo transversal, realizado com 503 mestrandos e doutorandos do Centro-Oeste brasileiro, usando o WHOQOL-BREF para analisar sua qualidade de vida. A análise incluiu o coeficiente alfa de Cronbach, análise fatorial confirmatória e análises bivariada e multivariada. Resultados: maior idade e ter filho associaram-se com maiores escores médios de qualidade de vida, enquanto diagnóstico de ansiedade/depressão, dificuldade em gerir atividades acadêmicas e pessoais e pensar em desistir do curso foram associados a menores escores médios nos domínios da qualidade de vida $(p<0,05)$. Conclusões: estudantes de mestrado e doutorado têm redução da qualidade de vida durante todo o período de formação, principalmente na saúde psicológica e física. A gestão das atividades acadêmicas e desistir do curso são as principais variáveis associadas a diminuição da qualidade de vida desses estudantes.

Descritores: Qualidade de Vida; Educação de Pós-Graduação; Estudantes; Saúde Mental: Profissões de Saúde.

\section{RESUMEN}

Objetivos: evaluar la calidad de vida de los estudiantes de maestría y doctorado en el área de la salud. Métodos: estudio transversal, realizado con 503 estudiantes de maestría y doctorado del Medio Oeste brasileño, utilizando el WHOQOL-BREF para analizar su calidad de vida. El análisis incluyó el coeficiente alfa de Cronbach, el análisis factorial confirmatorio y los análisis bivariados y multivariados. Resultados: la edad avanzada y tener un hijo se asociaron con puntuaciones medias más altas para la calidad de vida, mientras que el diagnóstico de ansiedad/depresión, la dificultad para manejar las actividades académicas y personales y la idea de abandonar el curso se asociaron con puntuaciones medias más bajas en los dominios de calidad de vida $(p<0,05)$. Conclusiones: los estudiantes de maestría y doctorado han reducido la calidad de vida durante todo el período de formación, principalmente en salud psicológica y física. La gestión de las actividades académicas y el abandono del curso son las principales variables asociadas a la disminución de la calidad de vida de estos estudiantes. Descriptores: Calidad de Vida; Educación de Postgrado; Estudiantes; Salud Mental; Empleos en Salud. 


\section{INTRODUCTION}

The reflection on aspects of quality of life (QoL) of master's and doctoral students goes beyond traditional measures aimed at academic performance and/or diagnosis of diseases. The importance of this theme has been increasingly recognized in the world and in Brazil, highlighting the need to understand the damage in multiple aspects of life that may be inherent in the process of training the researcher ${ }^{(1-2)}$.

Master's and doctoral students conduct much of the research in the world, being one of the relevant sources of scientific advancement and human resources in teaching centers and universities ${ }^{(1)}$. However, the work process, which is often stressful, has been associated with a real risk of illness and impairment of various aspects of these students' ${ }^{\prime}$ ives ${ }^{(1,3)}$. Thus, the need to monitor the exhaustion of graduate students in the health field is highlighted, as they often have higher levels of burnout than peers of the same age and the general population. Moreover, burnout in graduate health students can affect their mental health, empathy and professional conduct ${ }^{(4)}$.

Most master's and doctoral students experience negative situations/conditions during their training that can impair their QoL. Recent studies show that stress was present in percentages ranging from $33.4 \%$ to $51.0 \%$ of students'reports ${ }^{(5-7)}$, and workload in graduate school was pointed out by $47.4 \%$ of this population ${ }^{(7)}$. Another study ${ }^{(8)}$ observed that $16.0 \%$ of graduate students had anxiety disorder and their relationship with their supervisors was assessed as negative by $96.3 \%$ of these students.

Literature suggests that, among stricto sensu graduate students (PGSS) in health, stress, female gender and the last academic year are associated with significant impairment of mental and physical components of $\mathrm{QoL}^{(5,9-10)}$. Furthermore, health and social relationships may be the components most affected in the QOL of these students, as evidenced by the lowest score in the domains of general health and social aspects ${ }^{(11)}$.

Considering that QoL is a sensitive indicator of conditions of life, health and social interaction experienced by individuals, reflecting their culture, values and expectations ${ }^{(12)}$, it is observed that literature on QoL assessment of master and doctoral students is still is incipient. Current studies are restricted to the diagnosis of stress, stressors and mental illnesses, limiting the understanding of sociodemographic factors that can influence students' $\mathrm{QoL}^{(5,13)}$. Despite advances in investigations, most studies identified on the QoL of master's and doctoral students include students in the pharmacy area ${ }^{(5,9-10)}$ and confirm the relationship between stress and mental and physical components of QoL.

\section{OBJECTIVES}

To assess the quality of life of master's and doctoral students in the health field in their formative years and explore sociodemographic factors that influenced students' quality of life.

\section{METHODS}

\section{Ethical aspects}

This study followed the current guidelines for experiments with human beings in Brazil, obtaining approval from the Research Ethics
Committee in 2017, in accordance with Resolution 466/12 ${ }^{(14)}$. All participants agreed to participate in the study on a voluntary basis through an Informed Consent Form and their identity was preserved.

\section{Study design, period, and place}

This is a cross-sectional study conducted in the first semester of 2017 in nine federal graduate programs in the Center-West of Brazil, guided by the STROBE tool.

\section{Population or sample; inclusion and exclusion criteria}

Master's or doctoral students in health were invited, based on the list of e-mail contacts provided by graduate programs. In these programs, a master's degree lasts approximately three years and a doctorate lasts approximately four years. In the first year, master's and doctoral students take mandatory and optional subjects and develop their research project for an ethics committee. In the second year, they are involved in collecting data, preparing their dissertation/theses for qualification. In the third year of their master's degree, they produce manuscripts for submission to scientific journals and defense of the final product (dissertation). Finally, in the fourth year, doctoral students produce manuscripts for submission to scientific journals and defense of the final product (thesis).

Students enrolled and pursuing a master's or doctorate in one of nine programs at a public educational institution in a capital of the Brazilian Center-West, with at least thirty days of course, considering this time as sufficient to have started their contact with the academic scenario were included ${ }^{(2)}$.

The distribution of academic activities during the course years is related to the national guidelines for assessment and development of graduate studies in Brazil ${ }^{(15)}$. Assessment has among its indicators training time of the researcher, being a negative factor to exceed the expected time for completion of the course. Thus, Brazilian graduate programs tend to require students to complete activities within an estimated period of up to three and four years, for master's and doctorate degrees respectively.

\section{Study protocol}

All students answered the survey instruments through an electronic form independently and anonymously, after accessing information about the study and providing their consent to participate in the research. Participants who did not return the invitation email within 30 days were excluded from the study.

The data collection instrument contained two parts. The first collected the sociodemographic variables gender, age, children or dependents under 18, self-reported diagnosis of anxiety and/ or depression, year of entry into graduate school, academic level and professional training. It was also questioned whether students thought of giving up graduate school were satisfied with the relationship with their supervisors and if they had difficulty in reconciling graduate school with personal life in the last 30 days.

The second part of the instrument consisted of the Brazilian version of the WHOQOL-BREF ${ }^{(16)}$, a generic instrument for assessing QoL of the World Health Organization, used to assess QoL of both sick people and healthy individuals. The instrument consists of 26 items or questions, divided into four domains: physical (7 
items), psychological (6 items), social relationships (3 items) and environment (8 items). The accounting of domain scores was performed based on the instrument's official syntax ${ }^{(12)}$.

For analysis of the WHOQOL-BREF, each questionnaire was checked for completion of the 26 questions with values from one to five and whether it was completed in at least $80 \%$ (or more than six questions). Subsequently, the values of questions three, four and 26 were inverted, since they are constructed with an inverted response scale. Domain scores can range from 0 to 100 , with higher scores indicating better QoL ${ }^{(12)}$.

\section{Analysis of results, and statistics}

Quantitative variables are presented as median and interquartile range, or mean and standard deviation (SD). Qualitative variables were described with frequency and percentage.

TheWHOQOL-BREF's internal consistency was determined using the Cronbach coefficient, with values equal to or greater than 0.70 being considered acceptable ${ }^{(17)}$. The structural validity of the instrument was verified through confirmatory factor analysis (CFA). Data covariance matrix (24 items) was obtained from an initial four-factor model. To check the difference between means of QoL scores (dependent variable) and sociodemographic characteristics (independent variable), bivariate and multivariable analyzes were performed. In bivariate analysis, Student's t test for independent samples or Analysis of Variance (ANOVA) was used. Spearman's correlation test was performed to verify the relationship between age and $Q$ oL domains. $P$ value of $p$ $<0.05$ was considered statistically significant. Variables that presented $\mathrm{p}<0.10$ and age and sex due to the potential confounding effect, were included in the multiple linear regression analysis stepwise method. For each model, the standardized Beta coefficient and the explained variance (R2) were estimated. Variables with $p$ values $<0.05$ were considered statistically significant.
In Table 1, structural validity was assessed by means of CFA, in order to assess the similarity between the hypothetical structure of the Brazilian version of the questionnaire and the data observed between master and doctoral students. The results showed a KaiserMeyer-Olkin measure equal to 0.914 and Bartlett's sphericity test equal to $X^{2}=4613.96$ and $p<0.001$, which indicated that the sample in this study was adequate for factor analysis. CFA adjustment for the four models can be considered acceptable, when seven pairs of items belonging to the same domain were allowed to be correlated; $\mathrm{X}^{2}=804.9, \mathrm{RMSEA}=0.069, \mathrm{NFI}=0.829, \mathrm{CFI}=0.872$. Furthermore, the load of all items in the questionnaire was greater than or equal to 0.3 , suggesting adequate construct validity (Table 1 ).

Table 2 identifies that no statistically significant association was found between the means of QoL domains score according to the year of graduate school and academic level ( $p>0.05$ ). Despite this, there was a moderate tendency to increase the means of QoL domains with the advance of the academic year.

Spearman's correlation showed a significant relationship between age and domain physical health $(\rho=0.118 ; p=0.008)$; psychological $(\rho=0.191 ; p<0.001)$; environment $(\rho=0.218 ; p$ $<0.001)$; except for social relationships $(\rho=-0.004 ; p<0.926)$. Thus, the results show that older master's and doctoral students may have a higher score in most QoL domains, however, age had moderate predicting power in the population studied.

Table 3 shows that female students have lower mean in the domain physical health score than male students $(p<0.05)$. Students with self-reported diagnosis of anxiety and/or depression, frequent difficulty in reconciling graduate studies with personal life and who thought about giving up graduate school in the last 30 days presented lower mean in the scores of all QoL domains $(p<0.05)$. Furthermore, dissatisfaction with the relationship with the counselor and being a nurse was associated with a decrease in the scores of physical health and social relationships domains $(p<0.05)$.

\section{RESULTS}

The study sample consisted of 503 students, representing a response rate of $63.0 \%(\mathrm{~N}=$ 503/799). The median age was 30 years (interquartile range of 9), and most participants identified themselves as female 411 (81.7\%). Additionally, 99 $(19.7 \%)$ were in the first year, 197 (39.2\%) in the second year and $207(41.2 \%)$ in the third year or more of the course.

The WHOQOL-BREF questionnaire in general had a Cronbach's alpha coefficient of 0.918 ; for physical health, psychological, social relationships and environment domains, Cronbach's alpha coefficient was $0.777,0.774,0.662$ and 0.769 , respectively.
Table 1 - Factor loading of WHOQOL-BREF items, Brazil, 2017

\begin{tabular}{|c|c|c|c|c|}
\hline Domains & $\begin{array}{l}\text { Physical } \\
\text { health* }\end{array}$ & Psychological* & $\begin{array}{l}\text { Social } \\
\text { relationships* }\end{array}$ & Environment* \\
\hline 03. Pain and discomfort & 0.484 & & & \\
\hline 04. Dependence on medicinal substances and medical aids & 0.397 & & & \\
\hline 10. Energy and fatigue & 0.756 & & & \\
\hline 15. Mobility & 0.462 & & & \\
\hline 16. Sleep and rest & 0.542 & & & \\
\hline 17. Activities of daily living & 0.770 & & & \\
\hline 18. Work capacity & 0.715 & & & \\
\hline 05. Positive feelings & & 0.634 & & \\
\hline 06. Spirituality/religion/personal beliefs & & 0.593 & & \\
\hline 07. Thinking, learning, memory and concentration & & 0.530 & & \\
\hline 11. Bodily image and appearance & & 0.562 & & \\
\hline 19. Self-esteem & & 0.796 & & \\
\hline 26. Negative feelings & & 0.535 & & \\
\hline 20. Personal relationships & & & 0.738 & \\
\hline 21. Sexual activity & & & 0.555 & \\
\hline 22. Social support & & & 0.525 & \\
\hline 08. Physical safety and security & & & & 0.705 \\
\hline 09. Physical environment: (pollution/noise/traffic/climate) & & & & 0.512 \\
\hline 12. Financial resources & & & & 0.595 \\
\hline 13. New information and skills & & & & 0.456 \\
\hline 14. Recreation and leisure & & & & 0.624 \\
\hline 23. Home environment & & & & 0.504 \\
\hline 24. Health and social care & & & & 0.454 \\
\hline 25. Transport & & & & 0.443 \\
\hline
\end{tabular}

Note: *Confirmatory factor analysis, factor loading. 
Table 2 - Average scores of quality of life domains of master's and doctoral students according to academic year, Brazil, 2017

\begin{tabular}{|c|c|c|c|c|c|}
\hline \multirow{2}{*}{$\begin{array}{l}\text { Quality of life } \\
\text { domains }\end{array}$} & \multicolumn{3}{|c|}{ Ano acadêmico } & \multirow[b]{2}{*}{$\mathbf{F}$} & \multirow[b]{2}{*}{$P^{*}$} \\
\hline & Ano 1 & Ano 2 & $\begin{array}{c}\text { Ano } 3 \\
\text { ou mais }\end{array}$ & & \\
\hline \multicolumn{6}{|l|}{ Physical health } \\
\hline Master's degree & $64.4 \pm 18.1$ & $65.7 \pm 16.4$ & $65.7 \pm 16.1$ & 0.167 & 0.846 \\
\hline Doctoral degree & $61.0 \pm 15.1$ & $66.1 \pm 16.1$ & $67.0 \pm 15.8$ & 1.795 & 0.169 \\
\hline \multicolumn{6}{|l|}{ Psychological } \\
\hline Master's degree & $58.6 \pm 17.0$ & $58.8 \pm 17.2$ & $62.2 \pm 15.1$ & 1.300 & 0.274 \\
\hline Doctoral degree & $60.7 \pm 15.7$ & $62.6 \pm 16.7$ & $64.0 \pm 15.8$ & 0.557 & 0.574 \\
\hline \multicolumn{6}{|l|}{ Social relationships } \\
\hline Master's degree & $61.8 \pm 18.7$ & $60.2 \pm 19.9$ & $62.2 \pm 18.8$ & 0.208 & 0.812 \\
\hline Doctoral degree & $57.8 \pm 18.2$ & $63.1 \pm 20.4$ & $61.4 \pm 19.1$ & 0.763 & 0.467 \\
\hline \multicolumn{6}{|l|}{ Environment } \\
\hline Master's degree & $60.9 \pm 15.2$ & $62.5 \pm 14.7$ & $63.7 \pm 13.3$ & 0.728 & 0.484 \\
\hline Doctoral degree & $65.2 \pm 16.7$ & $63.1 \pm 15.8$ & $64.5 \pm 14.4$ & 0.300 & 0.741 \\
\hline
\end{tabular}

In Table 4, the multivariate analysis showed that advancing age is significantly associated with better QoL in social relationships and environment aspects $(p<0.001)$. Having children positively influenced the psychological domain of QoL $(p=0.036)$, while depression and anxiety significantly decrease physical health and psychological domains $(p=0.001)$. It is noteworthy that students who had frequent difficulty in reconciling graduate studies with personal life, as well as those who thought about dropping out of course, presented reduced QoL in all their domains.

\section{DISCUSSION}

The present study suggests that the WHOQOL-BREF is reliable and valid for assessing QoL of master's and doctoral students in health through online platforms. There was no significant difference in QoL between academic years, suggesting that

Table 3 - Sociodemographic and academic characteristics of master's and doctoral students of Brazilian graduate programs $(N=503)$, Brazil, 2017

\begin{tabular}{|c|c|c|c|c|c|}
\hline \multirow[b]{2}{*}{ Variables } & \multirow[b]{2}{*}{ n (\%) } & \multicolumn{4}{|c|}{ Quality of life domains } \\
\hline & & $\begin{array}{l}\text { Physical health } \\
\text { Mean } \pm \text { SD }\end{array}$ & $\begin{array}{c}\text { Psychological } \\
\text { Mean } \pm \text { SD }\end{array}$ & $\begin{array}{c}\text { Social relationships } \\
\text { Mean士SD }\end{array}$ & $\begin{array}{c}\text { Environment } \\
\text { Mean } \pm \text { SD }\end{array}$ \\
\hline \multicolumn{6}{|l|}{ Sex } \\
\hline Female & $411(81.7)$ & $64.8 \pm 16.5^{\mathrm{a}}$ & $60.6 \pm 16.3$ & $61.7 \pm 19.0$ & $63.2 \pm 14.7$ \\
\hline Male & $92(18.3)$ & $69.3 \pm 15.1$ & $63.5 \pm 16.9$ & $60.1 \pm 18.6$ & $63.6 \pm 15.1$ \\
\hline \multicolumn{6}{|c|}{ Children or dependents under 18 years old } \\
\hline Yes & $124(24.7)$ & $66.8 \pm 16.1$ & $64.9 \pm 16.0^{\mathrm{a}}$ & $58.9 \pm 19.2$ & $65.0 \pm 13.6$ \\
\hline No & $379(75.3)$ & $65.2 \pm 16.4$ & $59.6 \pm 16.4$ & $62.2 \pm 19.2$ & $62.7 \pm 15.0$ \\
\hline \multicolumn{6}{|l|}{ Anxiety and/or depression } \\
\hline Yes & $164(32.6)$ & $59.0 \pm 16.6^{a}$ & $53.6 \pm 17.2^{\mathrm{a}}$ & $57.0 \pm 20.6^{a}$ & $60.4 \pm 15.6^{a}$ \\
\hline No & $339(67.4)$ & $68.8 \pm 15.2$ & $64.8 \pm 14.8$ & $63.5 \pm 18.2$ & $64.6 \pm 14.1$ \\
\hline \multicolumn{6}{|c|}{ Difficulty in reconciling graduate school with personal life } \\
\hline Often & $233(46.3)$ & $58.6 \pm 16.2^{b}$ & $54.9 \pm 16.4^{b}$ & $53.9 \pm 19.5^{b}$ & $58.8 \pm 14.7^{b}$ \\
\hline Sometimes & $185(36.8)$ & $69.2 \pm 14.0$ & $64.5 \pm 14.4$ & $65.0 \pm 15.9$ & $65.6 \pm 12.7$ \\
\hline Never & $85(16.9)$ & $77.1 \pm 12.0$ & $70.9 \pm 13.6^{b}$ & $73.8 \pm 16.6$ & $70.3 \pm 14.9$ \\
\hline \multicolumn{6}{|l|}{ Relationship with supervisor } \\
\hline Dissatisfied & $51(10.1)$ & $62.7 \pm 15.9^{b}$ & $56.9 \pm 16.0$ & $56.2 \pm 20.7^{\mathbf{b}}$ & $60.0 \pm 15.4$ \\
\hline Neither satisfied nor dissatisfied & $78(15.5)$ & $62.1 \pm 14.3$ & $59.4 \pm 14.1$ & $58.8 \pm 17.5$ & $61.2 \pm 14.1$ \\
\hline Satisfied & $374(74.4)$ & $66.7 \pm 16.7$ & $62.1 \pm 16.9$ & $62.6 \pm 19.3$ & $64.1 \pm 14.7$ \\
\hline \multicolumn{6}{|c|}{ Thought about dropping out of graduate school } \\
\hline Yes & 238(47.3) & $60.4 \pm 15.4^{b}$ & $55.2 \pm 14.9^{b}$ & $56.3 \pm 18.5^{b}$ & $59.1 \pm 14.3^{b}$ \\
\hline No & $265(52.7)$ & $70.3 \pm 15.8$ & $66.5 \pm 16.0$ & $65.9 \pm 18.8$ & $66.9 \pm 14$ \\
\hline \multicolumn{6}{|l|}{ Training } \\
\hline Nurse & $150(29.8)$ & $62.7 \pm 16.0^{\mathrm{a}}$ & $59.9 \pm 15.8$ & $58.3 \pm 19.1^{\mathrm{a}}$ & $61.8 \pm 14.1$ \\
\hline Other category & $353(70.2)$ & $66.9 \pm 16.3$ & $61.7 \pm 16.7$ & $62.7 \pm 19.2$ & $63.8 \pm 15.0$ \\
\hline
\end{tabular}

Table 4 - Sociodemographic and academic variables associated with the means of the WHOQOL-BREF domains, applied to master's and doctorate students in the health area $(\mathrm{N}=503)$, Brazil, 2017

\begin{tabular}{|c|c|c|c|c|}
\hline \multirow[b]{2}{*}{ Variables } & \multicolumn{4}{|c|}{ Quality of life domains } \\
\hline & $\begin{array}{c}\text { Physical health } \\
\beta^{*}\end{array}$ & $\begin{array}{c}\text { Psychological } \\
\beta^{*}\end{array}$ & $\begin{array}{c}\text { Social relationships } \\
\beta^{*}\end{array}$ & $\begin{array}{c}\text { Environment } \\
\beta^{*}\end{array}$ \\
\hline Sex (female) & 0,055 & 0,022 & $-0,017$ & $-0,013$ \\
\hline Age (years) & 0,063 & 0,085 & $0,160^{\mathrm{b}}$ & $0,161^{b}$ \\
\hline Children or dependents under 18 years (yes) & - & $0,090^{\mathrm{a}}$ & - & - \\
\hline Diagnosis of anxiety and/or depression (yes) & $0,192^{b}$ & $0,227^{\mathrm{b}}$ & 0,057 & 0,056 \\
\hline Difficulty in reconciling graduate studies with personal life (frequent) & $0,353^{b}$ & $0,285^{\mathrm{b}}$ & $0,231^{\mathrm{b}}$ & $0,234^{b}$ \\
\hline Dissatisfied with the relationship with their supervisor (yes) & 0,049 & - & 0,048 & - \\
\hline Thinking about dropping out of graduate school (yes) & $0,160^{\mathrm{b}}$ & $0,213^{b}$ & $0,164^{b}$ & $0,172^{b}$ \\
\hline Training (nurse) & 0,035 & - & 0,017 & - \\
\hline Adjusted R2 & $26,8 \%$ & $27,2 \%$ & $18,0 \%$ & $14,6 \%$ \\
\hline
\end{tabular}

Note: ${ }^{*} \beta=$ standardized beta coefficient; ${ }^{a} p<0.05 ;{ }^{b} p<0.001$ 
factors that are detrimental to QoL affect students during the entire training process. Younger people, children or dependents under the age of 18 , anxiety and/or depression, difficulty in reconciling graduate school with personal life, relationship with a supervisor, thinking about giving up graduate school and academic training were associated with worse QoL of students in different domains.

The WHOQOL-BREF proved to be a possible tool to be applied on a large scale by electronic means, maintaining reliability parameters similar to the validation study ${ }^{(16)}$. Confirmatory factor analysis showed acceptable characteristics, confirming the instrument's structure in the studied population. However, the Cronbach coefficient of the social relationship domain $(a=0.662)$ did not present a minimum value recommended by literature ${ }^{(17)}$. A possible reason for this phenomenon includes the number of items in this domain $(n=3)$, which may have reduced the value of the coefficient despite its validity, as a limitation of the test ${ }^{(17)}$.

Evidence suggests that the collection method in the assessment of psychological constructs may generate changes in the results obtained ${ }^{(18)}$. A recent study showed higher concurrent validity and less bias in responding to social convenience in computer mode than in intercom mode ${ }^{(18)}$. However, this study did not include psychometric tests such as factor analysis and Cronbach's coefficient, as we did in the present study. Thus, the WHOQOL-BREF empirical analysis in master's and doctoral students confirms that it is possible to maintain the internal structure and consistency of an online self-completion instrument.

In the context of future research, the current study showed the need to monitor students' $\mathrm{QoL}$ and interventions throughout academic course. Furthermore, short terms and the high number of academic activities may be related to the difficulty of master's and doctoral students in balancing/reconciling their social and academic roles ${ }^{(7,19)}$. In this process, students dispense intense physical and psychological energy, which can lead to fatigue ${ }^{(20)}$, reduce free time for social relationships and leisure opportunities and overload them ${ }^{(7)}$, compromising QoL during training, as evidenced in this study.

Literature suggests universal measures to prevent illness in universities, including the inclusion of supervisory activities and the need for strategies to help develop the skills expected for the course through workshops, tutorials, financial and psychological support ${ }^{(21)}$, sustainable proportion of students per supervisor and continued leadership development in supervision ${ }^{(22)}$.

The construction of preventive programs and strategies must also consider students' sociodemographic characteristics. In the current study, most participants were female and had worse physical health than their peers. This data reflects the historical link between courses in health and the figure of women, still present in society ${ }^{(23)}$. Additionally, the decrease in the physical domain of QoL results from work capacity, energy and general health conditions ${ }^{(16)}$, which suggests a higher frequency of physical exhaustion among them when compared to men. This data may be related to the greater sensitivity of women to academic stressors and to overload of social roles (mother, wife, worker) ${ }^{(2)}$.
Another relevant variable for QoL was having children or dependents under 18 years of age, which was related to the higher average psychological health of the participants in the current study. This positive relationship may be associated with the fact that having children can represent a sense of purpose, greater subjective well-being and great pleasure in time with them ${ }^{(24)}$. Literature review showed that the interference in individual and marital well-being is greater when children live at home, with a tendency of negative effect among young parents and positive in older age ${ }^{(25)}$.

The self-reported diagnosis of depression and/or anxiety significantly decreased all domains of QoL in the population studied. These mental disorders may be associated with physical and psychological changes that compromise the performance of individuals in their entirety ${ }^{(26)}$ and contribute to increasing the risk of death and disability worldwide ${ }^{(27)}$. These data reinforce the need for educational institutions and health services to offer psycho-emotional support to master's and doctoral students.

In the current study, it was also shown that dissatisfaction with their supervisors can decrease students' physical health and social relationships. Supervisors play a central role in conducting academic work, as they are a necessary reference for students' academic experience ${ }^{(28)}$. Lack of feedback ${ }^{(29)}$, little quantity and little use of meetings ${ }^{(2)}$ and lack of inspirational leadership by supervisors ${ }^{(1)}$ are factors that can generate dissatisfaction.

It was also evident that students who thought or were thinking about giving up the course showed losses in all areas of QoL. Considering the high financial and scientific investment in training master's and doctoral students ${ }^{(1)}$, interruption of the course and students' illness represent loss of human capital and a public health problem. This data alerts to the importance of teaching policies in graduate studies that consider the academic environment as a space for health promotion ${ }^{(28,30)}$.

The promotion of the health of nursing master's and doctoral students deserves to be highlighted in this context. In our study, nurses had worse physical health and social relationships than their peers. This data has reflected in the exhaustion and overload of nursing professionals, who in general have a high workload ${ }^{(31)}$, which favors illness and reduces time for personal relationships. It is worth noting that nursing plays a key role in the quality of care and graduate students have the potential to contribute to evidence-based practices ${ }^{(32)}$.

The current study showed that sociodemographic variables, especially mental health and the difficulty of managing professional activities and personal life, can help understand the mechanisms of illness of individuals who perform work that involves a large number of stressors, such as master's and doctoral students. Work stressors can cause illness in several economic segments ${ }^{(3-3-34)}$; in this study, we found different aspects of life that can be harmed in this relationship, in addition to the already established knowledge about graduate students' mental health ${ }^{(1,13,29)}$.

The adaptive responses of individuals to stressful environmental factors constitute a means to understand mechanisms for maintaining and restoring balance in a physiological and socially non-damaging way ${ }^{(35)}$ and, consequently, of QoL. 


\section{Study limitations}

The current study had some limitations as graduate programs are from only one region of the country, not representing the entire demographic diversity of Brazilian programs.

\section{Contributions to nursing and health}

Assessment of the QoL of master's and doctoral students favors the understanding of multiple aspects of students' lives and provides preventive measures. The results of this study provide support for understanding the impacts of PGSS experience on students, an aspect still neglected due to the current fragility of knowledge on the subject. From a political point of view, this work encourages the discussion of current graduate education policies, aiming to improve the academic experience through interventions aimed at groups likely to have their QoL compromised. The data from this study, allows its use as a model and incentive for new assessments of QoL and may favor the training of coordinators of PGSS programs to recognize academic aspects harmful to students' QoL.

The negative effects of work stressors cause illness in several economic segments, and in this study, different aspects of life were found that can be harmed, in addition to the already established knowledge about mental health. Thus, this study redirects future research into the use of multidimensional instruments, such as the WHOQOL-BREF, in the assessment of academic experience and the development of support programs in graduate courses, with an emphasis on sociodemographic and academic variables relevant to QoL pointed out in the survey.

\section{CONCLUSIONS}

The study showed that the WHOQOL-BREF online is a good tool for assessing the QoL of master's and doctoral students in health. QoL does not differ significantly between academic years. Younger people, not having children or dependents under 18 , having anxiety and/or depression, difficulty in reconciling graduate school with personal life, relationship with a supervisor and thinking about giving up graduate school were associated with lower scores in different domains of students' QoL.

It is necessary that graduate programs consider implementing strategies of academic and psychological support to minimize damage to QoL, considering the sociodemographic specificities of students throughout the course.

\section{ACKNOWLEDGEMENT}

We are grateful for the master's scholarship offered to the first author of this study during part of her training by the Brazilian National Council for Scientific and Technological Development (CNPq - Conselho Nacional de Desenvolvimento Científico e Tecnológico).

\section{REFERENCES}

1. Levecque K, Anseel F, De Beuckelaer A, Van der Heyden J, Gisle L. Work organization and mental health problems in PhD students. Res Pol [Internet]. 2017[cited 2017 Sep 08];46(4):868-79. Available from: http://www.sciencedirect.com/science/article/pii/S0048733317300422

2. Faro A. Estresse e estressores na pós-graduação: estudo com mestrandos e doutorandos no Brasil. Psicol Teor Pesq [Internet]. 2013[cited 2017 Sep 15];29(1):51-60. Available from: https://doi.org/10.1590/S0102-37722013000100007

3. Evans TM, Bira L, Gastelum JB, Weiss LT, Vanderford NL. Evidence for a mental health crisis in graduate education. Nature Biotech[Internet]. 2018 [cited 2019 Jun 13];36(1):282. Available from: http://dx.doi.org/10.1038/nbt.4089

4. Bullock G, Kraft L, Amsden K, Gore W, Prengle B, Wimsatt J, et al. The prevalence and effect of burnout on graduate healthcare students. Can Med Educ J [Internet]. 2017 [cited 2019 Dec 26];8(3):e90-e108. Available from: https://www.ncbi.nlm.nih.gov/pmc/articles/PMC5661741/

5. Awadh Al, Aziz NA, Yaseen SN, Abdulameer SA, Sahib MN, Al-Lela OQB. A comparison study of perceived stress and quality of life among Master of Pharmacy and non-pharmacy master's students. Pharmacy Educ [Internet]. 2013 [cited 2017 Sep 12];13(1):22-8. Available from: http://pharmacyeducation.fip.org/pharmacyeducation/article/view/219

6. Beall JW, DeHart RM, Riggs RM, Hensley J. Perceived stress, stressors, and coping mechanisms among Doctor of Pharmacy Students. Pharmacy [Internet]. 2015 [cited 2017 Sep 19];3(4):344-54. Available from: http://www.mdpi.com/2226-4787/3/4/344/pdf

7. Brown K, Anderson-Johnson P, McPherson AN. Academic-related stress among graduate students in nursing in a Jamaican school of nursing. Nurse Educ Pract [Internet]. 2016[cited 2017 Mar 29];20:117-24. Available from: http://www.sciencedirect.com/science/article/pii/S1471595316300683

8. Jungbluth C, MacFarlane IM, Veach PM, LeRoy BS. Why is everyone so anxious?: an exploration of stress and anxiety in genetic counseling graduate students. J Genet Counsel[Internet]. 2011 [cited 2017 Sep 22];20(3):270-86. Available from: http://link.springer.com/article/10.1007 \%2Fs10897-010-9348-3

9. Marshall LL, Allison A, Nykamp D, Lanke S. Perceived Stress and Quality of Life Among Doctor of Pharmacy Students. Am J Pharm Educ[Internet]. 2008 [cited 2017 Sep 11];72(6):137. Available from: http://www.ncbi.nlm.nih.gov/pmc/articles/PMC2661164/

10. Gupchup GV, Borrego ME, Konduri N. The impact of student life stress on health related quality of life among doctor of pharmacy students. Coll Stud J [Internet]. 2004 [cited 2017 Sep 22];38(2):292-301. Available from: https://www.researchgate.net/ publication/209835887_The_Impact_of_Student_Life_Stress_on_Health_Related_Quality_of_Life_among_Doctor_of_Pharmacy_Students

11. Novais CAMM, Takada JAP, Silva KCC, Borgianni OB, Barcelos VM, Marques V. Qualidade de vida de estudantes em um programa de pósgraduação stricto sensu. Rev Ideário [Internet]. 2015 [cited 2017 Jun 11];3(5):85-92. Available from: http://www.ideiaeduc.com.br/uploads/ revista/pdf/desm/n5/085_saude_qualidade_de_vida.pdf 
12. The WHOQOL Group. WHOQOL-Bref: Introduction, Administration , Scoring and Generic Version of the Assessment [Internet]. Genebra (Suiça): Programe on mental health - World Health Organization; 1996 [cited 2017 Sep 15]. Available from: http://www.who.int/mental_health/media/ en/76.pdf

13. Ribeiro ÍJS, Pereira R, Freire IV, Oliveira BG, Casotti CA, Boery EN. Stress and quality of life among university students: a systematic literature review. Health Prof Educ [Internet]. 2017 [cited 2017 Sep 25];3(1):2-7. Available from: http://www.sciencedirect.com/science/article/pii/S2452301117300305

14. Ministério da Saúde (BR). Conselho Nacional de Saúde. Resolução № 466 de 12 de dezembro de 2012. Normas regulamentadoras de pesquisa envolvendo seres humanos. Brasília (Brasil): Ministério da Saúde; 2012.

15. Coordenação de Aperfeiçoamento de Pessoal de Nível Superior (CAPES). Portaria $n^{\circ}$ 59, de 21 de março de 2017. Dispõe sobre o regulamento da Avaliação Quadrienal da Coordenação de Aperfeiçoamento de Pessoal de Nível Superior - CAPES. Brasília (Brasil): CAPES; 2017.

16. Fleck MPA, Louzada S, Xavier M, Chachamovich E, Vieira G, Santos L, et al. Application of the Portuguese version of the abbreviated instrument of quality life WHOQOL-bref. Rev Saúde Pública. [Internet]. 2000[cited 2017 Sep 22];34(2):178-83. Available from: http://www. ncbi.nlm.nih.gov/pubmed/10881154

17. Cronbach LJ. Coefficient alpha and the internal structure of tests. Psychometrika[Internet]. 2019 [cited 2020 Jun 10];16(3):297-334. Available from: https://doi.org/10.1007/BF02310555

18. Zhang X, Kuchinke L, Woud ML, Velten J, Margraf J. Survey method matters: online/offline questionnaires and face-to-face or telephone interviews differ. Comput Human Behav [Internet]. 2017 [cited 2019 Dec 13];71:172-80. Available from: http://www.sciencedirect.com/ science/article/pii/S0747563217300791

19. Tijdink JK, Schipper K, Bouter LM, Pont PM, Jonge J, Smulders YM. How do scientists perceive the current publication culture? a qualitative focus group interview study among Dutch biomedical researchers. BMJ Open[Internet]. 2016 [cited 2017 Sep 22];6(2):9. Available from: http://bmjopen.bmj.com/content/bmjopen/6/2/e008681.full.pdf

20. Ilies R, Huth M, Ryan AM, Dimotakis N. Explaining the links between workload, distress, and work-family conflict among school employees: physical, cognitive, and emotional fatigue. J Educ Psychol. 2015;107(4):1136-49. https://doi.org/10.1037/edu0000029

21. Conley CS, Durlak JA, Kirsch AC. A Meta-analysis of universal mental health prevention programs for higher education students. Prev Sci. 2015;16(4):487-507. https://doi.org/10.1007/s11121-015-0543-1

22. Duke DC, Denicolo PM. What supervisors and universities can do to enhance doctoral student experience (and how they can help themselves). FEMS Microbiology Letters. 2017;364(9):fnx090. https://doi.org/ 10.1093/femsle/fnx090

23. Zhang W, Liu Y-L. Demonstration of caring by males in clinical practice: a literature review. Int J Nurs Sci. 2016;3(3):323-7. https://doi. org/10.1016/j.jijnss.2016.07.006

24. Musick K, Meier A, Flood S. How Parents Fare: mothers' and fathers' subjective well-being in time with children. Am Sociol Rev [Internet]. 2016 [cited 2019 Dec 13];81(5):1069-95. Available from: https://journals.sagepub.com/doi/abs/10.1177/0003122416663917

25. Hansen T. Parenthood and happiness: a review of folk theories versus empirical evidence. Soc Indicators Res. 2015;108(1):29-64. https://doi. org/10.1007/s11205-011-9865-y

26. Cordioli AV. Manual diagnóstico e estatístico de transtornos mentais. Porto Alegre: Artmed; 2014 [cited 2019 Dec 13]. Available from: http:// aempreendedora.com.br/wp-content/uploads/2017/04/Manual-Diagn\%C3\%B3stico-e-Estat\%C3\%ADstico-de-Transtornos-Mentais-DSM-5.pdf.

27. World Health Organization (WHO). Depression and other common mental disorders: global health estimates [Internet]. Geneva: WHO; 2017 [cited 2017 Nov 11]. Available from: http://apps.who.int/iris/bitstream/10665/254610/1/WHO-MSD-MER-2017.2-eng.pdf

28. Devos C, Boudrenghien G, Van der Linden N, Azzi A, Frenay M, Galand B, et al. Doctoral students' experiences leading to completion or attrition: a matter of sense, progress and distress. Eur J Psychol Educ [Internet]. 2016[cited 2017 Sep 25];32(1):61-77. Available from: http:// link.springer.com/article/10.1007\%2Fs10212-016-0290-0

29. Bazrafkan L, Shokrpour N, Yousefi A, Yamani N. Management of stress and anxiety among PhD students during thesis writing: a qualitative study. Health Care Manag [Internet]. 2016[cited 2017 Sep 10];35(3):231-40. Available from: https://www.ncbi.nlm.nih.gov/pubmed/27455365 